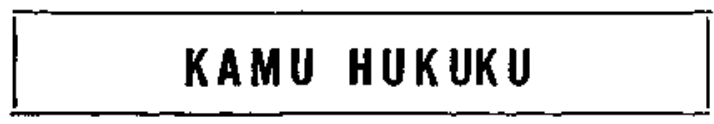

\title{
UÇAK KAÇIRMA SUÇLARI
}

\author{
Prof. Dr. Faruk EREM \\ Doç. Dr. Selâhattin KEYMAN
}

Konu, hava trafiğinin gelişimi ile ilgilidir. Ayrıca, hemen her memleket whava yollan işletmesi»ne sahiptir. Milletlerarası hava trafiği büyük ve işletmesi oldukça karışı, bu sebeple güvenliğinin korunması daha zorunIu hale gelmiş bir örgüttür. Bu açıdan, hukuk dışı müdahalelerin önlenmesinde milletlerarası çıkar vardır. Nitekim, son yıllarda pek sık diyebileceğimiz şekillerde tekrarlanan uçak kaçırma fiilleri, konunun milletlerarası seviyede düzenlenmesindeki zarureti göstermektedir.'

11948 Ocağından 1969 Eylül başlarına kadar 121 civarında uçak kaçırma fiilinin ișlendiği tesbit edilmiş bulunmaktadır. Bu devre zarfında, 1948 . 1950 (onyedi olay) ve 1958 - 1962 (onyedi olay) yılları arasında, uçak kaçırma fiillerinin sayısında bir yükselme müşahade edilmektedir. Ancak, Eylïl 1968'den Eylül 1969'a kadar, bundan evvelki yirmi yıllık devrede vuku bulanın toplamından daha çok sayıda uçak kaçırma fijli ișlenmiştir. 1969 yılında işlenen fiillerin artışındaki nisbet daha da barizdir. Bu ko. nudaki istatistikler, 1968 ylı içinde otuz, 1969'un ilk otuzỉç haftasında ise kırkaltı uçak kaçırma olayının vuku bulduğunu göstermektedir. Yukarıda sözü edilen ve uçak kaçırma fiillerinde belirli yükselmeleri gösteren devrelerden 1948-1950 yılları arası Çin ve Çekoslavakya'daki siyasi karışıklıkları; 1958-1962 yılları arası ise Küba'da Castro'nun iktidara ge. lis ve iktidarını tahkim ettiği zamana rastlamaktadır. Ancak, 1968 ve 1969 yllarındaki artış için tek bir izah tarzı bulmağa imkân yoktur. Bu verilen rakamlar sadece başarı ile gerçekleșen uçak kaçırma olaylarını kap. samaktadır. Bundan başka bir de, çoğu zaman failin niyet ve kastının açık bir şekilde anlaşılamamașından dolayı resmî belgelere geçirilmesi mümkïn olamayan bir çok uçak kaçırma teşebbìislerinin de mevcut bu. lunduğunu unutmamak gerekir (1969'da otuz kadar. Bu konuda bk. Evans, Alona: Aircraft hijacking: Its cause and cure, American journal of international law, 1969, s. 4. s. $697-698$, s, 697-698 dip not: 9-15; Bu konuda aynca bk. Fitzgerald, $\mathbf{G}$ erald: The development of international rules 
Esasen, hava nakil vasıtaları içinde ve bunlar vasitasıyla işlenen suçlar bakımıridan bir milletlerarası anlaşmaya olan ihtiyaç daima hissedilmiștir. Böyle bir ihtiyacın sebepleri ise, bilindiği üzere çeșitlidir: Bir kere, çeșitli iç hukuk sistemlerinin hava nakil vasıtaları içinde ve bunlar vasıtasıyla ișlenen suçlara iliş̧in hükümleri arasindaki farklar, konunun milletlerarası düzenlenmesini gerekli kılmaktadır. Öte yandan, bir devletin kendi taabiyetindeki hava nakil vasıtaları içinde veya bunlar vasıtasıyla işlenen suçlar bakımından kaza yetkisini düzenleyen milletlerarası kurallar mcvcut değildir. Üçüncui olarak da, yetki uyușmazlıkları meselesi, milletlerarası bir anlaşmaya duyulan ihtiyacon en belirli nedenlerinden biridir. ${ }^{2}$ Gerçekten de, hava nakil vasıtaları içinde işlenen suçlarda kaza yetkisi meselesi, gittikçe genişleyen hava trafiği sebebi ile 1920 'lerden beri Devletler Hukuku Komisyonu'nun önemle üzerinde durduğu konulardan biri olmuștur. Nihayet 1963' de Tokyo'da, bu ve bununla ilgili bazı meseleleri kapsayan bir sözleşme imzalanmıştır. ${ }^{3}$

Yetki uyuşmazlıkları meselesi, adi suçlar bakımından ikj önemli problem dợurmaktadır: İlk olarak, bir devletin ülkesinde, diğer bir devletçe tescil edilmiş uçak (yabancı) içinde veya bunun vasıtası ile işlenen suça hangi kanun uygulanacaktır? Öte yandan, herhangi bir devletin ïlkesi saylmayan yerlerde hava nakil vasıtalan içinde veya bunlar vasıtasıyla işlenen suçlara hangi kanun uygular:acaktır? Genellikle, durumun özelliğine göre, ya suçun işlendiği yer kanununun, ya ceza usul kanunlarına göre olaya el koyan mahkemenin kanununun, ya da bayrak kanununun uygulandığ 1 görülmektedir. Ancak, pozitif bukukta varılan bu sonuçların, çeşitli yetki uyuşmazlıklarına yol açtığı da bir gerçektir. Nitekim, uçuş halirıdeki bir hava nakil vasıtası içinde vukubulan bir suçun işlenmesine ilişkin özel şartlar ve bunun gibi, aynı olayda birden çok yetkililik iddiasının bulunabilmesi, yetki uyuşmazlı̆g ihtimallerini çơ̆galtmaktadır. Öte yandan, büyük bir hızla yol almakta olan bir hava nakil vasıtası içinde vuku bulan neticesi hareketten ayrılabilen suçta, hareket bir yerde ișlenmiş netice de bir başka yerde gerçekleşmiş olabilir ki, bu takdirde, iki ayrı yetkililik iddiası (hareketin yapıldığı yer ve neticenin gerçekleștiğ̣i yer kanunları) bir-

concerning offences and certain other acts committed on board aircraft, The Canadian Yearbook of International Law, 1963, s. 240 dip not: 24

2 Fitzgerald, Development, s. 232

3 Samuels, Alec: Crimes committed on board aircraft: Tokyo Convention Act 1967, British Yearbook of International Law, 1967, s. 271 
den ortaya çlkacaktır. Hatta, hava nakil vasıtaları büyük bir süratle ve çok yükseklerden uçabilmekte, çok kısa bir zaman fasılas1 içinde birkaç ülkenin üzerinden birden geçebilmekte ve bu suretle meselâ fiil icra edildiği anda hava nakil vasıtasınm hangi ülkede üzerinde bulunduğunu tayin imkânsızlașmaktadır. Büitün bu zorluklar, muhtelif yasamalar tarafindan, bazan bayrak kanununa, bazan ülkesine inilen devletin kanununa yetki tanımak ve nihayet bazan da özel bir «suçun işlendiği yer» (ki çoğu zaman bu yer uçaktır ve neticede bayrak kanunu uygulanmış olur) tayini sureti ile ortadan kaldırılmağa çalışılmıştır. ${ }^{4}$ Adi suçlarda olduğu gibi, uçak kaçırma fiillerinde de hangi kanunun uygulanacağı konusunda tereddütlere rastlanacağı tabiidir. Mülkilik ilkesinin, failin veya mağdurun tebası bulunduğu devlet kanununun, failin ele geçirildiği memleket veya iniş mahalli kanununun, bayrak kanununun uygulanması veyahut hareketin işlendiği her memleketin mahkemelerinin yetkili sayılması veya münhasıran milletlerarası bir mahkemenin yetkili kılınması konularında anlaşmaya ihtiyaç vardır.

Öte yandan, uçak kaçırma füli, iç hukuka ilişkin bazı meseleler de doğurmaktadır. Zira herşeyden evvel, uçak kaçırma füilinin iç hukuk (ceza hukuku) bakımından nasıl tavsif edilebileceğini araştırmak; ikinci olarak da, ülkesine uçak kaçırılan devletin ne gibi ytkilerí olduğunu tesbit etmek gerekmektedir. Nihayet konuya bir de, suçlularnn geri verilmesi yönünden bakmak icap etmektedir. Bütün bu nedenlerle, uçak kaçırma fiilini yukarıda sözüi ediIen açılardan incelemek gerekmektedir. Ancak bu çalışmada konu, önce mevcut iç ve dış hukuk kuralları bakımından incelenecek; bundan sonra da 14 Eylül 1963 tarihli Tokyo Sözleşmesi'nin ilgili hükümleri açıklanacaktır. Öte yandan, yetki uyuşmazlıklarının çözülmesi meselesi, uçak kaçırma fiilinin milletlerarası suç haline getirilmesinden sonra önemli problemler doguracağndan ve daha henüz bu anlamda bir milletlerarası metin mevcut bulunmadığından, yetki meselesinin önemine değinmekle yetinilecek ve ancak zaruri açıklamalar yapılacaktır.

I. Uçak kaçurma fiilinin ceza hukuku yönünden tavsifí: Uçak kaçırma fiilinin bir suç teşkil edip etmediğini ve suç teşkil ediyorsa, bunun hukuki tavsifinin ne olacağı meselesini ikiye ayırarak incelemek doğru bir yol gibi gözükmektedir: A. İ̧ hukuk yönünden, B. Devletler huku yönünden.

${ }^{4}$ Mankiewicz, R.H. : Aspect et problèmes du droit pénal de l'aviation internationale, Annuaire français de droit international, 1958, s. $127 \cdot 128$ 


\section{A. İç hukuk yönünden :}

Millî mevzuatta yol değiştirme fiillerine kısmen uygulanabilecek hükümler bulunabilir. Uçak adamlanna karşı «silâhla tehdit» (TCK. m. 188/3), yolcuların "şahıs hürriyetlerine karşı suç» (TCK. m. 179) ve benzeri hükümlerin uygulanabilmesi mümkün görünmektedir. Fakat bunlardan hiçbiri, milletlerarası hava trafiği bakımından güvenliği bozan asıl hareketi cezalandıramamaktadır. Her ne kadar iç hukukumuzda genel olarak "büyük tehlike suçları" na ilişkin hükümler (TCK, m. 396 vd.) ve bu arada ayrıca gemilere ve deniz seyrüseferinin güvenliğine ilişkin bazı suçlar (TCK. m. $377,379)$ mevcutsa da, ceza hukukundaki kıyas yasağı, bu konuda açık bir hükmü zaruri kılmaktadır. Diğer yönden, uçak kaçırmanın tek bir ülkenin sımırları içinde vuku bulması halinde, kullanma hırsızlığı olarak tavsif edilip hırsızlığa ${ }^{5}$ veya yağmaya ilişkin hükümlerin (TCK. m. 495) ${ }^{6}$ uvgulanması düşünülebilir. Bununla beraber, uçak kaçırma fiilini müstakil ve hiçbir karışıklığa meydan vermeyecek şekilde suç sayı unsurlarnn tayin eden iç hukuk kurallarına duyulan ihtiyaç açıktır. Ancak burada, suçun unsurlarının tesbitinde tereddüt edilebilir. Uçak kaçırma fiilleri için Ingilizce'de kullarilan «hijacking» terimi, genel olarak bir ticari nakil vasıtası veya geminin, içindeki eşya veya mal üzerinde hırsızlık suçunu işlemek gayesi ile ele geçirilmesi anlamını taşımasına ră̆men, söz kcnusu fiili tam olarak ifade edememektedir. Zira, uçak kaçırma suçunun esas unsurlarının hırsızlıkla pek ilgisi yoktur. Bu. rada daha ziyade, bir uçağı nakil vasıtası sıfatıyla özel gayeye uygun șekilde kullanmak üzere ele geçirmek veya gayesini buna uygun şekilde değiştirmek ve uçuş plânını zor kullanmak sureti ile bașka bir istikamete çevirmek söz konusudur. ${ }^{8}$

Bununla beraber, uçak kaçırma suçunda genel olarak mala karşı suçların (mamelekî suçlar) genel özelliklerinden birisini teşkil eden "menfaat sağlama» unsurunun bulunmadığını iddia etmek güiçtür. Bilindiği gibi, mala karşı suçların (mamelekî suçlar) çoğunda, cezalandırılan fiilin «menfaat sağlamak amacı ile» işlenmiş bulunması șartı aranmaktadır. Öte yandan, menfaat kavramı bugün oldukça geniş anlaşılmaktadır. Sadece ekonomik fayda, da-

\footnotetext{
${ }^{5}$ Kullanma hırsızlığı konusunda bk. Erem, Faruk : Ceza Hukuku Hususi Hükümler, Ankara 1968 , c. 2, s. 530 vd.

6 Yağma konusunda bk. Erem, Hususi Hükümler, c. 2, s. 557 vd.

${ }^{7}$ Aynı kanaat, Evans, agn?., s. 695

${ }^{8}$ Evans, agm., s. 696
} 
ha başka bir deyişle sadece mamelekteki bir artma değil, aynı zamanda işlenmiş bulunan fiilden duyulan herhangi bir memnuiyet ve zevk de menfaat sayılmaktadır.' Mala karşı suçların (mamelekì suçlar) en önemli örnekleri incelendiğinde, bunların hepsinde de "menfaat sağlama» gayesinin bir unsur olarak mevcut bulunduğu ve sözï edilen unsurun çoğu zaman bunları benzer suçlardan ayırmada öIçü teşkil ettiği görülmektedir. Nitekim hrsızlıkta (TCK. m. 491), menfaat sağlama niyeti (faydalanmak niyeti) bir unsur olarak müşahade edilmektedir. Usstelik burada menfaat, bir gayrrmenkulün zilyetliğinin ele geçirilmesini değil, mamelekî veya gayn mamelekî bir faydayı ifade etmektedir. Bu unsur aynı zamanda, hırsızlığın diğer benzer suçlardan ayrılmasında ölçü teşkil etmektedir. ${ }^{10}$ Kullanma hırsızlı̆ğnda da, menfaat sağlama yani faydalanma niyeti bakımından aynı sonuca varlacağı tabiidir. Ancak kullanma hırsızlığında bu faydalanmanın geçici bir zaman için olması hususunun, neticeyi değiştirmediğini yani burada da menfaat sağlama niyetinin mevcut bulunduğunu belirtmek gerekir." Aynı şekilde yağma (TCK. m. 495) da, esas itibariyle hirsızlıktan ibaret olduğundan, ancak faydalanma niyeti (menfaat sağlamak) ile hareket edildigi takdirde kabul edilebilir. Bunun gibi, bütün maIa karşı suçlar (mamelekî suçlar) da kabul edildiği üzere, menfaatin mamelekî olup olmaması arasında bir fark yoktur. ${ }^{12}$

Bütün bu verilen bilgiler, hangi saik ve maksatla ișlenmis bu bulunursa bulunsun, uçak kaçırma suçunda mala karşı suçların (mamelekî suçlar) esas unsurlarından birini teşkil eden menfaat sağlama niyetinin (faydalanmak niyeti) mevcut bulunduğunun ka. bul edilmesi sonucunu doğurur. Zira yukarıda da ifade edildiği üzere, menfaat sağlama (faydalanma), mutlaka malın mülkiyet ve zilyetliğini ele geçirme kastı anlamına gelmez. Esasen uçak kaçırmanun, her şeye rağmen hırsızlık teşkil ettiği Amerikan hukukunda da ifade edilmiștir. Nitekim Federal Havaclık Kanunu'nun 1961'. deki tadiline kadar uçak kaçırma fiillerinde koğuşturma, çalınmıș bir hava nakil vasıtasımı bir yerden diğer bir yere götürmek suçunden dolayı yapılmakta idi. Bunun yanında, şahısları ülke dışına

${ }^{9}$ Antolisei, Francesco (Çeviren: Alacakaptan, Uğur): Genel olarak mameleke karş1 işlenen suçlar, AHFD., 1962, n. 1.4, s. $78-79$

10 Manzini, Vincenzo: Trattato di diritto penale, Torino 1963, c. IX, s. 189191; Erem, Ceza Hukuku Hususi Hükümelr, c. 2., s. 537

"1 Manzini, age., s. 347; Ayrıca bk. Erem, Ceza Hukuku Hususi Hükümler, c. 2., s. 530 vd.

12 Erem, Ceza Hukuku Hususi Hükümler, c. 2., s. 562; Manzini, age., s. 421 
kaçırmak, tehdit ve şiddetle ticarî faaliyeti engellemekten dolayı yapılan koğușturmalara da rastlanmaktadır.13

Görüldü̈ü üzere, uçak kaçırma fiilinin müstakil suç sayılması halinde, bunun hangi kategori suçlara dahil sayllacağı konusunda tereddütler uyanabilmektedir. Nitekim, suç teșkil eden ayn bir hareketin çeşitli hukuki varlıkları ızrar etmesi veya tehlikeye koyması haline sık stk tesadüf edilmektedir. Böyle bir ihtimal esas itibariyle muhtelit, mürekkep ve biribirine bağll suçlarda söz konusu olmakla beraber, basit suçlar bakımından da ortaya çıkabilmektedir. Bu durumda hukuki konunun tayini suçun şu veya bu kategoriye sokulmasında «üstünlük» kriterine başvurulacaktır. Ancak bu konudaki hükmï, herhangi bir kontrole tâbi olmaksızın kendi politik değerlendirmesine göre kanun koyuunun verdiğini de belirtmek gerekir. Zira, belli bir fillle ihlâl edilen çeşitli hukuki varlıklar arasından kendisince daha önemli görülen ve suçun hukuki mahiyctine daha uygun geleni seçmek kanun koyucuya aittir. Böylece kanun koyucu, normun üstün gayesini tesbit etmiș olacaktır. ${ }^{14}$ Nitekim, bizim hukukumuzda da bunun misallerine rastlanmaktadır. Örneğin, iftira cürmünün konusunun ne olduğu (adliye idaresinin ihlâli ve șahsın șeref ve hürriyetinin ihlâli), uzun tartışmalara sebebiyet vermşitir. Modern yasamalar ile birlikte Türk kanun koyucusu, bu konuda, adlî faaliyetin muntazam şekilde icrasına vaki ihlâle üstünlük tanımış bulunmaktadır.15 Bunun gibi adam kaldırma suçunda da (TCK. m. 499), iki ayrı hukuki varlığın (hürriyet ve mamelek) ihlâl edildiği görülmektedir. Ancak, kanun koyucu burada daha ziyade mala kar\$sı suç (mamelekî suç) vasfına üstünlük tanımış ve ilgili normu buna göre koymuştur. Bu sebeple adam kaldırma, şahsa karşı maddi ve manevi ce. bir kullanmak sureti ile hırsızllktır. Yani burada cezaî himayenin konusu hem mamelek hem de hürriyet olduğu halde, ${ }^{16}$ kanun koyucu söz konusu suçu mala karşıı suçlardan (mamelekî suç) saymıștır. ${ }^{17}$

\footnotetext{
${ }^{13}$ Bu konuda bk. Evans, agm., s. $696-697$; s. 697 dip not: 9

${ }_{14}$ Toroslu, Nevzat: Cürümlerin tasnıfi bakımından suçun hukuki konusu (Bașımmamıș tez), Ankara 1969, s. 271

15 Toroslu, age., s. 272

16 Manzini, age., s. 377

17 "Konusu hem mamelek ve hem de kiși hürriyeti olduğuna göre, bu suçun (adam kaldırma) mala karșı suçlardan sayılması, diğer bir deyimle malike karşı işłenmiş olmak vasfının, hürriyete karșı olmak vașfından üstün tutulmasın isabetli görmemek de mümkündür». Erem, Ceza Hukuku Hususi Hükümler, c. 2, s. 570
} 
Verilen örneklerde cezaen korunan hukuki varlık bakımından ortaya çıkan zorluklar, uçak kaçırma fiili bakımından da söz konusudur. Bu itibarla, bir iç hukuk değișikliği yapmak ve bu gibi fiilleri müstakil suç saymak düşünüldüiğui takdirde, üstünlük kriterini uygulamak sureti ile hangi hukuki varlığa üstünlük tanınacağının da araştırılması gerekir. Zira, bir fiili suç sayarken bu suçun hukuki konusu da unsurlaran tesbiti kadar önemli olmaktadır. Nitekim, suçun şu veya bu gruba yerleştirilmesi yönünden bir kere seçim yapıldtktan ve herbir suçun hukuki konusu kesinlikle tesbit edildikten sonra, yorumcu, bu seçimi kabul etmek ve suçun hukuki mahiyetine ilişkin incelemelerini bu seçim etrafında toplamak zorundadır. ${ }^{\text {is }}$

Uçak kaçırma suçunun hangi hukuki varlığı ihlâl ettiği yani bu suçun hukuki konusunun ne olduğu konusundaki seçimin kanun koyucu tarafindan yapılacağını kabul etmekle beraber, bu konuda bazı teklifler ileri sürmek de mümkün olabilmektedir. Gerçekten de, son zamanlarda, devletler topluluğuna ait hukuki varlıklarm cezaen himayesi de söz konusu olmaktadır. Nitekim devletler topluluğu veya milletlerarası topluluk, daima daha da artan bir kısım ihtiyaçların suijesi olmaktadır. Bunlar, milletlerarası veya devletlerarası topluluğun mevcudiyetine ilişkin ihtiyaçlardır. Bu ihtiyaçları tatmin vasitaları ise, devletlerarası veya milletlerarası varlıklardır. Devletler hukuku, devletlerarası veya milletlerarası hak ve ödevlere sahip clma ehliyetini münferit devletlere tanımaktadır. Bununla beraber, bütün devletlere, yani devletler topluluğuna ait varliklar ve menfaatler ceza hukuku himayesinden faydalanmaktadırlar. Böyece devletler topluluğu da, cezaen himaye edilen var. lık ve menfaatlerin yani hukuki varlık ve menfaatlerin hâmili olarak ortaya çkmaktadır. Nitekim, devletler topluluğuna dahil olma vakıası, her devleti iç hukuku vasıtasıyla, sadece bir yabancı devlete ait hukuki varhk ve menfaatleri değil, ayn zamanda milIetlerarası topluluğa dahil bütün yabancı devletlerle müștereken sahip bulunduğu varlık ve menfaatleri yani milletlerarası topluluğa has varlık ve menfaatleri de korumağa zorlamaktadır. Milletlerarası denizlerin güvenliğine, bulașıcı hastalıkların bir ülkeden diğerine yayılmasını, beyaz kadın ve esir ticaretini önlemeğe ve denizaltı telefon ve telgraf kablolarının bütünlügüne ilişkin varlık. lar, milletlerarası varlıklara dahildirler.". Öyle ise uçak kaçırma suçunun da, «devletler topluluğuna ait hukuki varlıklara karşı suç»

${ }_{18}$ Toroslu, age, s. 272

19 Toroslu, age., s. 348 
sayılması düşünülebilir. Ancak buna karșı, aile, toplum, devletler topluluğu gibi hükmi șahsiyeti haiz bulunmayan kollektif organizmaların suçun pasif süjesini teşkil edemeyeceği iddiası ileri sürülebilir..$^{20}$ Hernekadar aile, toplum, devletler topluluğu gibi hükmi şahsiyeti haiz bulunmayan kollektif organizmalarn hak süjesi olamayacakları doğru ise de, suçun pasif süjesi olmak problemi menfaatleri hukuki bakımdan bir şahsa izafe etmek problemi değildir. Çünkü, devleti her suçun devaml pasif süjesi kabul etmek, cezaen himaye edilen menfaatleri bir şahsa izafe etmek ihtiyacına cevap vermektedir. Burada söz konusu problem, menfaatleri muayyen sosyal gruplar etrafinda toplayabilmek problemidir. Öyle ise devletler topluluğu da (aile ve toplum gibi), tıpk1 fert ve devlet gibi, suç tarafından ihlâl edilen hukuki menfaat veya varlığın hamili ve binnetice suçun pasif süjesi olabilir. ${ }^{21} \mathrm{Bu}$ itibarla, uçak kaçırmanın devletler topluluğuna karșı bir suç sayılması, ceza hukuku yönïnden hatalı olmayacaktır. Ancak bu takdirde, söz konusu suçun, șeklî bakımından. belli bir devletin iç hukukunu ihlâl ettiğini unutmamak gerekir.:2

Buraya kadar iç hukuk yönünden yaptığımız açıklamaları tamamlamak için bir noktanın daha nazara alınmsı gerekmektedir. Nitekim, mevcut TCK. hükümlerinin veya uçak kaçırma fiilini yukarıda açıklandığı şekilde müstakil suç haline getirecek bir iç hukuk kurahnıı tatbik edilebilmesi için, çoğu zaman, TCK.'nun ülke bakımından uygulanmasına ilişkin hükümlere (TCK. m. 3,4,5,6,7) bașvurmak gerekecektir.

\section{B. Devletler hukuku yönünden :}

1. İc hukuk kurallarmun yetersizliği : Milletlerarası düzen bakımından muhtelif ihtimaller akla gelebilir: Bir Türk veya yabancı, bir Türk ya da yabancı uçağm yolunu,

a. Türk havalarında iken değiștirip başka bir ülkeye inmeğe zorlamıș; veya,

${ }^{20} \mathrm{Bu}$ anlayısı savunanların görüşleri için bk. Toroslu, age,, s. 196 vd.; Ayrrca bk. Antolisei, Francesco: L'offesa e il danno nel reato, Bergamo 1930; Grispigni, Filippo: II carattere sanzionatorio del diritto criminale, Milano 1920

${ }^{21}$ Toroslu, age., s. 172-173; Ayrica bk, Bettiol, Giuseppe: Diritto penale, parte generale, Palermo 1952, s. 554

22 Toroslu, age., s. 349

${ }^{23}$ TCK'nun ïlke bakımmndan uygılanmast konusunda bk. Erem, Faruk: Türk Ceza Hukuku Genel Hükümler, C. I., Ankara 1968, s. 142 vd. 
b. Türk havalarından çıtıktan sonra değiștirip yabancı bir ülkeye inmeğe zorlamıştır.

Diğer bir ihtimal de, herhangi bir uçağın yolunun, bir Türk veya yabancı tarafından Türk havaları dışında deģiştirilip Türkiye'ye inmeğe mecbur edilmesidir. Bütün bu hallerde, Türk pozitif hukuku bakımından iki hususun araştırılması gerekecektir :

a. Fiil iç hukukumuz bakımından cezalandırılabilir bir fiil midir? Yani yukarndaki ihtimallerden herhangi biri, TCK. tarafundan suç olarak tarif edilen tipik bir fiil teşkil eder mi? Bu sorunun cevabın bulabilmek için, bir evvelki başlıkta zikredilen hükümlerin uygulanıp uygulanamayacağmı araștırmak gerekir.

b. Füilin, TCK. tarafından suç olarak tarif edilen tipik bir fiil olduğu sonucuna varılsa bile, TCK.'nun ülke bakımından uygulanmasına ilişkin hükümlerde (TCK. m. 3,4,5,6,7) aranan șartlarm gerçekleșip gerçekleșmediğini tesbit etmek gerekecektir. Ancak, bu suçların bazan siyasi saikle işlenmesi, bizim hukukumuz bakımından önemli problemler dogurmaktadır.

Bilindiği üzere, ssuçlularm geri verilmesini düzenleyen TCK. m. $9 / 2$ de, "Siyasi ve ona murtabit cürümlerden dolayı bir ecnebinin ecnebi devletlere idasi talebi devletçe kabul edilemez: denilmektedir. Sözü edilen hüküinde «siyasi ve ona murtabıt» cürümler denilmiş olmasından, bunun siyasi suçla irtibatı olan bütüin suçları, yani muhtelit ve murtabıt suçları içine aldı̆̆ sonucu çıkmaktadır. Nitekim, murtaibıt siyasi suçlardan dolayı geri verilmezlik kaidesini kabul eden kanunumuzun, siyasi suçla daha fazla alâkası bulunan muhtelit suç bakımından farklı bir sonuç kabul ettiğini iddia için muteber bir gerekçe bulmak da kolay değildir. ${ }^{24}$ Öte yandan Yargıtay da, siyasi suç konusunda oldukça geniș bir kıstas kabul etmiş bulunmaktadır. ${ }^{25}$ Bu itibarla, sık sık vuku bulmakta bulunan uçak kaçırma fiillerinin bizim hukukumuz bakımmndan bir suç teşkil ettiği kabul edilse bile, zaman zaman siyasi suç saylabileceklerini de gözden uzak tutmamak icap eder. Bu gibi fiil-

24 Ögen, Eralp: Suçluların geri verilmesi, Ankara 1962, s. 104

25 "Adi bir suçun siyasi bir suç mahiyetini iktisap etmesi behemhal fiilen ve maddeten siyasi bir suçun işlenmesine veya işlenmesi tasavvur edilmesine mütevakkıf olmayıp teessüs eden rejime muhalif bir siyasi telâkki besleyenlerin bu siyasi fikir ve telâkkilerinden dolayı nefislerine ağır tehlikeler tevlid edecek surette haksiz muarnelelere ve hususi bir nezaret ve takibe maruz kalmaları adi bir fiilin siyasi bir fille irtibatmm kabulüne esas teşkil.. «eder ve siyasi sayılır. 1 CD. 13.4.1949 1010/687 BK. Özgen, age., s. 104 
lerin tazan siyasi suç sayllabilmeleri, bir yandan geri vermeyi imkânsız kıldı̆̆ı gibi öte yandan da, bunların faillerinin Türkiye'de yargılanamäraları sonucunu doğurmaktadır. Gerçi TCK.'nda bu konuda açık bir hüküm yoktur. Fakat Yargıtayımız hakhı olarak, siyasi suçlunun geri verilmemesinden beklenen faydalan gerçekleștirebilmek için vazgeçilmez bir sonuç olarak ortaya çıkan bu "yargılanamama" kuralımı da kabul etmiş bulunmaktadır. Bu itibarla, kaçak siyasi suçlular geri verilmedikleri gibi, kendilerini Türkiye'de yargılamak da mümkün değildir. ${ }^{26}$ Uçağı Türkiye'ye kaçranın Türk olması halinde de netice değişmeyecektir. Zira, failin herşeyden evvel Türk vatandaşı olması dolayısıyla geri verilmesi söz konusu edilemeyecektir (TCK. m. 9/1); ve ayrica yukarıda sözü edilen kural sebebi ile Türkiye'de yargılanması da mümkün olamayacaktır. Esasen bu, Mehaz Kanunda kabul edilmiş bulunan sonuca da uygun düş̧mektedir. ${ }^{27}$

2. Uçak kaçırma fillinin devletler hukuku tarafindan düzenlenmesi zarureti : Buraya kadar yapılan açıklamalar, mevcut iç hukuk kurallarımızın uçak kaçırma fiillerinin ortaya çıkardığı problemleri çöznicğe yeterli clmadığını göstermektedir. Öte yandan, meselenin çözümlenmesi milletlerarası düzeni de ilgilendirmektedir. Bu itibarla, konunun düzenlenmesi için devletler hukuku kurallarmın konulmasina ve bundan senra da konulacak devletler hukuku kurallarına uygun iç hukuk kurallarına ihtiyaç vardır. Nitekim Ingiltere 1963 tarihli Tokyo Sözleşme'sini nazara alarak, iç hukukuna ilişkin hususłarı kapsayan bir 1967 tarihli Tokyo Sözleșneși Karuru çıkartmak sureti ile, Tokyo Sözleşmesi'nin Ingiltere tarafından tasdikini mümkün kılacak iç hukuk değişikliklerini yapmıștur. ${ }^{28}$

\footnotetext{
${ }^{26}$ Aynı kanaat Özgen, age., s. 106; Dönmezer, Sulhi - Erman, Sahir; Nazari ve tatbiki ceza hukuku, c. II/2, Istanbul 1964, s. 1202; Yargitay $1 \mathrm{CD}$. 13.1.1949 tarih ve $1010 / 687$ sayll karannda, TCK. m. 9 geregince geri verilcmeyen siyasi suçlunun, TCK. m. 6'daki șartların mevcut bulunması halinde, Türkiye'de yargılanabileceğini kabul etmiştir. Bk. Dönmezer - Erman, age., s. 1202 dip not: 98; Ancak esas mahkemenin israr üzerine YCGK., israrı onamis ve bu suretle aksi neticeyi yani geri verilemeyen siyasi suçlınun Türkiye'de yargılanamayacağını kabul etmiştir. CGK. 3.10.1949 1/108/93. Bu karar için bk. Perinçek, Sadık - Ozden, Cahit: Türk Ceza Kanunu ve buna ait seçilmiş Temyiz Mahkemesi kararları, Istan. bul 1959 , s. 17 vd.

${ }^{27}$ Bk. Mehaz Kanun m. 5, 6, 7

${ }^{28} \mathrm{Bu}$ konuda bk. Samuels, agm., s. $271 \cdot 277$
} 
GörüIdüğü üzere, uçak kaçırma filleri bakımından milletlerarası bir düzenlemeye duyulan ihtiyaç açıtır. Bu suretle, uçak kaçırma fiilinin milletlerarası suç ${ }^{29}$ olarak tavsifi mümkün olabilecektir. Gerçekten de bu fiilleri meselâ deniz haydutluğu (korsanlık) ${ }^{30}$ gibi milletlerarası suç haline getirmek için yeterli sebep var. dır. Böylece, uçak kaçırma suçu unsurları itibari ile tarif edilmiş ve yetki meselesinin halli bakımından hangi fiillerin böyle bir suç teșkil ettiği tesbit edilmiș olacaktır. Nitekim deniz haydutluğu bakımından bu yola gidilmis ve hangi fiillerin deniz haydutluğu sayllacağ́1 1958 Cenevre Açıdkdeniz Sözleșmesi'nin 15. maddesinde gösterilmek sureti ile, sözü edilen milletlerarası suç tarif edilmiş bulunmaktadır. ${ }^{31}$ Bundan sonra da, aymı sözleşmenin 19. maddesinde, yetki meselesine ilișkin hükümler yer almaktadır. ${ }^{32}$ Fakat, herhangi bir devletin açık denizde deniz haydudunu yakalayıp kendi mahkemelerinde yargılayabilmesi, herşeyden evvel, fiilin 1958 tarihli $\mathrm{Ce}$ nevre Açkdeniz Sözleșmesi'nin 15. maddesindeki tarife uymasına bağlıdır. ${ }^{33}$ Bütün tunlar, ilk olarak, uçak kaçırma fiilini milletlerarası suç haline getiren bir anlașmamn yapılması ve bu suretle söz konusu suç tarif edildikten sonra da yetki uyuşmazlıklarn meselesini halleden devletler hukuku kurallarının konması gereğini orta ya çıkarmaktadır. Nitekim, son zamanlarda, uçak kaçırmanın milletlerarası suçlar listesine ilâve edilmesi gereken bir fiil haline gelmiş bulunması vakıasına ve konunun milletlerarası seviyede dïzenlenmesi lüzumuna ișaret edilmektedir.$^{34}$ Esasen Avrupa Konseyi, üye devletleri, uçaklara yol değiștirtme fiillerine karşı birlikte tedbir almağa davet etmiştir; ayrıca Türkiye Birleșmiș Milletler'de alınan karar katılmis bulunmaktadır. Bu suretle, Türk hukukunda da bazı yeni hükümlere ihtiyaç hasıl olmuștur. Birleşmiş Milletlerdeki çalıșmalarda, uçaklara «hukuk dısıı her müdahale»ye karșı üye devletlerin uygun kanun hükümleri koymaları, gerekli tedbirleri almaları ve suçluların takibi lüzumuna ișaret olunmuștur.

${ }^{29}$ Milletlerarası suç kavramı için bk. Meray, Seha L. : Devletler hukukuna giriş, c. I., Ankara 1960, s. 190 vd.

30 Deniz haydutluğu (korsanlık) için bk. Meray. age., s. 467 vd; Çelik, Edip: Milletlerarasi hukuk, c. II/1, IstanbuI 1968, s. 213 vd.; Gidel, G.: Le droit international public de la mer, 1932, c. I., s. 203 vd.

${ }^{31} 1958$ Cenevre Açıkdeniz Sözleşmesi'nin 15. maddesinde yer alan deniz haydutluğu suçunun tarifi için bk. Çelik, age., s. 214, 215; Ayrıca deniz haydutluğunun tarifi ve bu konuda açıklama için bk. Lütem, tlhan: Birleş. miş Milletler Deniz Hukuku Konferansi, Ankara 1959, s. 238 vd.

32 Bk. Çelik, age., s. 215 vd.

${ }^{33}$ Meray. age., s. 467

${ }^{34}$ Bk. Evans, agm., s. 695 
Bugün, uçak kaçırma fiilini milletlerarası suç sayan bir devletler hukuku kuralına rastlanmamaktadır. Buna mukabil, 1963 tarihli Tokyo Sözleşmesi'nde uçak kaçırma fiiline ilişkin hükümler yer almaktadır. Ancak bu Sözleşme, uçak kaçırma fiilini bir milletlerarası suç haline getirmediği gibi, devletleri söz konusu fiilleri suç saymağa zorlayan hüküimler de ihtiva etmımektedir. Tokyo Sözleşmesi'nde, sadece uçağın iadesine, ülkesine inilen devletin yetkilerine, uçak kaçırma fiilini işleyen kimssenin tabi tutulacağı muameleve ilișkin hükümlere rastlanmaktadır. Sonuç olarak denilebilir ki, Tokyo Sözleşmesi, uçuş sırasında işlenen bazı suçlar bakımından yeni hükümler getirmiştir; fakat bu Sözleșme uçaklara cebirle yol değiştirtme hususurıda yetersiz kalmaktadır. Bu itibarla, çalışmamizın bundan sonraki kismında, uçak kaçırma suçunu milletlerarası suç saymak düşünüldüğü takdirde hangi ölçülerin nazara alıması gerektiği üzerinde durulacak ve bir de Tokyo Söz: leşmesi'nin uçak kaçırma fiili ile ilgili olarak getirmiş bulunduğu düzenleme incelenecektir.

II. Uçak kaçırma fiilini milletlerarası suç saymada kullanılabilecek ölçüler ve Tokyo Sözleșmesi Hükümleri :

A. Uçak kaçırma fïlini milletlerarası suç saymada kullanılabilecek ölçuiler : Bu yeni suça "uçak çalma», "uçak kaçırma», "hava korsanlığı» adları verilmeiktedir. Bir çeșit kullanma hrrsızlığı, zilyetliğin gayrı kanuni ele geçirilmesi anlamlarına gelmek üzere "uçak hırsılığı», cebir ile işlenmesi sebebi ile de «korsanlık» terimleri uygun görülebilir. Fakat bu fiiller, başlıca konusu «mal» clan suçlardan değildirler; böyle bir saikle işlenmiş sayılmazlar. Gerçekten de, son yirmi yıl içinde işlenmiş bulunan uçak kaçırma fiilleri, esas gayenin hava nakil vasıtasını çalmak veya mürettebat yahut da yolcular üzerinde hırsızlık suçunu işlemek olmadığını göstermiştir. Öte yandan, zaman zaman, kaçınlan hava nakjl vasıtasının zorla indirildiği devlet ülkesinde alıkonduğu görülmektedir; ancak daha çok siyasi sebeplerle bu yola gidildiği de bir gerçektir. ${ }^{35}$ Esasen, Milletlerarası Sivil Havacılık Teșkilâtı'nın Hukuk Komisyonu'nun hava nakil vasitalarının gayrı kanuni olarak ele geçirilmesi konusu ile ilgili alt komisyonu, hazırladığı bir milletlerarası sözleșme taslağında (Şubat 1969 tarihli toplantı), uçak kaçırma fiilini bir milletlerarası suç olarak tarif etmiş bulunmaktadır. Bu tarif de, hırsızlık ve genel olarak mala karşı suçlarda aranan ve özellikle kast ve saike ilişkin hususiyetlerin bu fiilin unsur-

${ }^{35}$ Evans, agm., s. 696, s. 696 dip not: 8 
ları arasında yer almadığın göstermektedir.$^{36}$ Nitekim sözü edilen taslağın 1. maddesine göre, uçuş halindeki hava nakil vasıtasının içinde işlenen aşağıdaki fiiller uçak kaçırma suçunu teşkil eder : a) Gayrı kanuni olarak, kuvvet kullanmak sureti ile veya tehditle, yolunu değiştirmek için bir hava nakil vasıtasını ele geçirmek yahut da bunun üzerinde kontrol icra etmek; b) Böyle bir hareketin icrasına teşebbüs etmek; ve nihayet, c) Böyle bir fiili ișleyen veya icrasına teşebbüs eden kimsenin hareketine suç ortağı olarak katılmak. Sözleşme taslağı, ayrıca 5. maddesinde yetki meselesine dokunmakta ve a) hava nakil vasitasinn tescil edildiği devletin, b) ülkesine ilk inilen devletin veya suç işlediği iddia edilen kimsenin ülkösinde hava nakil vasıtasını terkettiği devletin ceza koğuşturması bakımından yetkili olduğunu ifade etmektedir. ${ }^{37}$ Öte yandan, Birleşmiş Milletler çalıșmalarında ise "uçuş halinde iken cebir kullanmak sureti ile uçağın yolunu değiștirme suçu» deyimi kullanılmıștır $\mathrm{ki}$, bunun maksada daya uygun olduğu ileri sürülmektedir ${ }^{36}$ Ancak unutmamak gerekir ki, fiilin milletlerarası suç sayliması, milletlerarası ceza yetkisine sahip bir mahkeme mevcut bulunmadıkça, sadece yetki ve yetki uyuşmazlıkları meselesini halledebilecektir. Bu itibarla, milletlerarası anlașmalarda ayrnca, devletleri bu fiili iç hukukları bakımından suç saymağa zorlayan hükümlerin kabulü, vazgeçilmez bir zarurettir. Zira aksi halde, milletlerarası suç sayılan böyle bir fiili işleyen şahsı ele geçiren âkit devlet, söz konusu fiili cezalandırmak bakımından imkansızlık içinde kalabilecektir. Gözönünde bulundurulması gereken bir diğer husus da, gerek suçun unsurlarn gerek korunan hukuki varlık bakımından iç hukuk ile milletlerarası hukuk normları arasında asgari bir benzerliğin sağlanması lüzumudur. ${ }^{39}$

Bu fiilleri, "milletlerarası suç» (korsanlık, beyaz kadın ticareti, kalpazanlık, uyuşturucu maddeler, insanlığa karşı çürümler gibi) haline getirmek için yeterli sebepler vardır. Fakat, söz konusu suçun tanımında ve unsurlarmın tesbitinde «saik» açısından bazı güçlükler kendisini göstermektedir. Gerçi "saik»in, bu suçu benzeri suçlardan ayırmada ölçü teşkil edebileceği düşüüülebilir. Bununla beraber, failde mutlaka, bir başka ïlkede "sığınma hakkı"

${ }^{36}$ Bu konuda bk. yuk. I., A. vd.

${ }^{37} \mathrm{Bk}$. Evans, agm., s. $708-709$

${ }^{38}$ Bu konuda bk. Nationes Unies, Assembleé Générale 21 novembre 1963, A/C. $6 /$ SR. 1154

${ }^{39}$ Uçak kaçırma suçunun hukuki konusu ve cezaen korunan menfaat hakkinda bk. yuk. I., A. vd. 
elde etmek saikinin bulunması șart değildir. Yolculardan birisini, bir bașka ïlkeye teslim etmek için de bu suç işlenebilir. Öyle ise, bu suçu diğerlerinden ayırabilecek «saik»in önceden tesbitinde güçlükler vardır. Nittekim Amerika'da Adalet Bakanlığı'ndan verilen bilgilere göre, teșhis edilebilen krrkdokuz failden ondördünün sabıkalı, dördünün polis tarafmdan aranan kimseler olduğu tesbit edilmiș bulunmaktadır. Yine bunlar arasında ü̧̧ asker kaça. ğı olduğu ve ikisinin bazı ilișkilerinden doğan zorluklar sebebi ile uçak kaçrrma fiilini işledikleri ifade edilmiştir. Öte yandan, sayıları altı cvarında bulunan olayda ise, suçlular, Amerika'daki yaşama şartlarından memnun olmadıkları için uçak kaçırmak sureti ile Küba'ya iltica etmek yolunu tercih etmişlerdir. Nihayet üç olayda, siyasi maksatlarlla adam kaçırma gayesinin güdüldügüi tesbit edilmiștir.40

Bir ihtimal olarak da, genel olarak siyasal saikle işlenen uçak kaçırma fiillerinin milletlerarası suç sayılması düșünülebilir. Ancak unutmamak gerekir ki, söz konusu suçun «saik» açısından siyasi suç sayılması halinde, suçluyu geri verme mümkün olamayacağından, ${ }^{41}$ bu çeşit fiillerin milletlerarası suç sayılmasindan elde cdilecek sonuçlar pek büyük olmayacaktır. Ancak milletlerarası arlaşmalara konacak ve Belçika șartına ${ }^{42}$ benzeyen bir hükümle, uçak kaçırma fiillerinde suçlunun geri verilmesini mümkün kılabilmiek bakımından, tunların siyasi suç sayılamayacağının öngörülmesi düşüinuilebilir. Ancak, böyle bir yol da mahzurlu olacaktır. Bir kcre, aslında siyasi olan ve öyle saylması gereken bir suç, geri vermeyi mümkün kılabilmek için siyasi olmaktan çıkartıldı̆̆ takdirde, suçluların geri verilmesi müessesesinin esaslarma aykırı hareket cdilmiş ve bir bakıma geriye dönülmüss olacaktır. Zira, siyasi suçlardan dolayi geri verilmezlik, son zamanlarda kabul edilmiş bir kuraldır. Bu kuralın ortaya çıkmasında, siyasi suç anlayışının ve devletlerin siyasi suçlara karşı tutumlarmın tekâmülü büyük rcl oynamıștır. Hatta, devletlerin siyasi suç anlayıșı ve siyasi suça karşı tutumları ile siyasi suçlularm geri verilmemesi kuralı arasında bir sebep netice ilişkisi mevcuttur. Gerçekten de, eski devirlerde bu kuralın tamamen aksinin kabul edilmiş bulunduğu ve özellikle siyasi suçluların geri verilmekte olduğu müşahade edil. mektedir. Bundan sonra uzun bir devrenin geçmesini beklemek

40 Evans, agm., s. $700-701$, s. 701 dip not: 26

41 Siyasi suçlardan dolayı geri verilmezlik kuralı hakkında bk, Özgen, age., s. 76 vd.

42 Belçika şartı hakkında bk. Özgen, age., s. 90-93 
gerekmiş ve ancak Fransız ihtilâlinden sonra, liberal cereyanlar sonucunda siyasi suç hakkındaki yeni ve farklı görüşler ile birlikte, siyasi suçluların geri verilmeyeceği kuralı doğmuştur. ${ }^{43}$ Iște aslında siyasi clarak nitelendirilmesi gereken belli bir uçak kaçırma fiilini, geri vermeyi mümkün kllabilmek için siyasi suç olmaktan çkarırsak, suçluların geri verilmesi müessesesinin gelişiminde ters istikamette hareket etmiş oluruz. Esasen, bu konunun da incelendiği ve görüş ayrıhklarının ortaya çıktığı müşahade edilmektedir. Gerçekten de, ileride inceleyeceğjmiz Tokyo Sözleşmesi'nin uçak kaçırma fiilleririn işlenmesini önlemek bakımından tatminkâr görülmemesi sebebi ile, Milletlerarası Sivil Havacılık Teşkilâtı'nın Hukuk Komisyonu 1968 yllında, hava nakil vasitalarınm gayr kanuni olarak ele geçirilmesi konusu ile ilgili alt komisyonundan, suçluların yakalanmalarını ve koğușturulabilmelerini kolaylaştıran bir milletlerarası sözleșme taslağı hazırlamasını istedi. Burada hazırlanan tasarıda (Şubat 1969'daki toplantı), uçak kaçırma fiili milletlerarası suç sayıldığı gibi, suçlunun geri verilmesini mümkün kılan bir hüküm de kabul edildi. Bu tasarnm 8. maddesine göre, a) uçak kaçırma fiili, muhtelif âkit devletler arasında halen movcut veya ileride aktedilecek olan suçlularm geri verilmesi ant. laşmalarında, geri vermeyi mümkün kılan bir suç olarak kabul edilecektir; b) suçluların geri verilmesini bir antlaşmanın mevcudiyeti şartına veya karşılıklılık ilkesinin varlığına bağlı tutmayan âkit devletler, uçak kaçırma fiilini, geri vermeyi mümkün kılan bir suç olarak kabul edeceklerdir; ve nihayet c) bu fiil suçluların geri verilmesi bakımından sadece vuku bulduğu yerde değil, aynı zamanda hava nakil vasıtasının tescil edildiği devlet ülkesinde de işlenmiş sayilacaktır. Görüldüiğü üzere tasarıda, siyasi saik yönünden herhangi bir istisna yer almış değildir; esasen üye devletlerde, tasarnn böyle bir istisnayı ihtiva etmesi fikrine karșı kuvvetli bir muhalefet müşahade edilmiştir. Böylece alt komisyonda çoğunluğun kanaatı, bir devletin siyasi saik sebebi ile suçlunun geri verilesi talebini reddedebileceł̆gi yolunda tezahür etmiştir. Görülduiğui üzere sözüi edilen tasarnnın geri verme ile ilgili 8. maddesinde, bir çok geri verme antlaşmasında yer alan siyasi suç istisnasının (siyasi suçlunun geri verilmeyeceği kuralının), zımnen de olsa mevcut bulunduğunu iddia etmek mümkün olabilmektedir. Neticede, bu koruyucu çare, uçak kaçırma failleri bakımından herzaman başvurulabilecek bir yol olarak kalmaktadır. Bununla

${ }^{43}$ Ozgen, age., s. 76-80; Siyasi suç̧uların geri verilemeyeceği kuralının tarihi geliş̧imi için bk. Ozgen, age., s. 76 vd. 
beraber, böyle bir sözleşme yapıldığı takdirde, siyasi suç bakımmdan hiç bir hüküm koymamaktansa, devletlerin «siyasi saik» iddiası bakımından takdir yetkilerinin bulunduğunu gösteren açık bir ifadenin kullanılmalsı daha gerçekçi bir davranış olacaktır. ${ }^{4}$ Ancak, bugün yürürlükte bulunan Tokyo Sözleșmesinde ise, bu Sözleşmenin hiçbir hükmünün, suçluyu geri verme konusunda bir meoburiyet yaratır șekilde kabul edilemeyeceği açıkça ifade edilmiş bulunmaktadır (Bk. Sözleşme, m. 16/2).

Öte yandan, uçak kaçırma fiilini işleyeni, suçu siyasi saymamız sebebi ile geri vermezsek, bu sefer de kendi ülkemizde yargılayıp yangılayamayacağımız meselesi ortaya çrkar. Bu ise, esas itibariyle iç hukuku ilgilendiren bir mesele olduğundan, bütïn devletler bakımından yeknesak bir uygulamaya ulaşabilmek pek gü̧ görünmektedir. Nihayet, uçak kaçırma fiilini bir bütün olarak siyasi suç saymamak akla gelebilir. Ancak, olayların bir kısmında dahi olsa, siyasal saikin meveut bulunduğu bir gerçektir. Bu itibarla, siyasi maksatla işlendiği takdirde söz konusu suçu siyasi saymamak, gerçeklere aykırı hareket etmek olur. ${ }^{45}$ Eğer suç esasen siyasi saikle ișlenmemiş ise zaten mesele yoktur; zira bu gibi durumlarda milletlerarası bir düzenleme mutlak surette zaruri değildir. Siyasi sayılamayacak uçak kaçırma fiilleri bakımınđan, ceza kanunlarının ülke bakımından uygulanmasına ilișkin kurallar ve diğer jç hukuk kuralları, özellikle gerekli değișiklik ve tamamlamalar yapıldıktan sonra, çoğı zaman meseleyi çözmeğe yctebilecoktir. An Ancak bu konuda, bizdeki iç hukuk kurallarına bazı yeni kükümler ilâve edilmesi gereği de açıktır. Aynca, devletleri, uçak kaçırma fiilini sarih şekilde suç sayan iç hukuk kuralları kabul etmeğe meclur tutan bir milletlerarası anlaşmanın bu konuda çok yararlı olacağı da tabiidir.

Saik yanında "cebir» de, suç unsuru olarak önem arzetmektedir. «Maddi cebir» gibi «manevi cebir» (tehdit) in de suçun unsuru olarak kabul edilmesi doğru gözükmektedir. Bununla beraber, pilotu ikna sureti jle yol değiştirilmesini sağlama halinde, fiilin mücyyide dışı kalabilmesi ihtimali de düşündürücü bir mesele olarak karşımıza çıkmaktadır.

${ }^{44}$ Evans, agm., s. 709-710

${ }^{45}$ Siyasi suç konusunda en geçerli olduğunu sandı ไ̆ımız üstïnlïk ve sübjektif kıstaslarıncian hangisi kabul edilirse edilsin, bu suçlardan bir kısmının siyasi saylması gerektiği sonucuna varılacaktır; Siyasi suçu tayin de Sübjektif nazariye ve Üstïnlük nazariyesi için bk. Özgen, age., s. 72

${ }^{4}$ Bk. yuk. I., A. vd. 
Nihayet, failin uçakta bulunması şartını aranıp aranmayacağı hususunda da tereddüt edilebilir. Pilot, uçakta bulunmayan bir kimse tarafindan telsizle tehdit edilmek sureti ile yol değiștirmeğe içbar edilmiş ise, ne yaplacaktır? İște böyle bir ihtimal hallinde ne şekilde hareket edileceğinin de tesbit edilmesi gerekmektedir.

B. 1963 tarihli Tokyo Sözleşmesi'nłn uçak kaçrrma fiillerine ilłşkłn hükü̈mleri : ${ }^{47}$ Tokyo Sözleşmesi, uçak kaçırma fiilini, bunu milletlerarası bir suç saymak yönünden ele almamaktadır. Bu itibarla, Tokyo Sözleşmesi'nde uçak kaçırma milletlerarası bir suç olarak tarif edilmiş ve unsurları gösterilmiş değildir. Bununla beraber, söz konusu Sözleşme, âkit devletleri, uçağın veya kontrolu. nun gayr kanuni olarak ele geçirilmesini takiben bazı tedbirler al. mağa zorlamaktadır. ${ }^{43}$ Bu itibarla fail, herhangi bir âkit devlet tarafından nezaret altına alınabilir; ceza koğuşturmasına tâbi tutulabileceği gibi geri verilmesi de mümkündür.49 Öyle ise Sözleşme, sadece bu yönden önemli olabilmektedir. Ancak yolcular, mürettabat, fiili işleyen kimse ve uçak bakımından ne gibi tedbirlerin öngörüldüğünü incelemeğe başlamadan evvel, bu tedbirlerin hangi hallerde uygulanacağını, yani Tokyo Sözleşmesi hưkü̈mlerinin hangi fiillere şamil olduğunu tesbit etmek gerekmektedir.

Bir önceki paragrafta sözü edilen konuda, Tokyo Sözleşmesi'nin 11. maddesine başvurmak gerekmektedir. Nitekim, sözü edilen maddenin 1. fikrasinda, kuvvet kullanmak sureti ile veya tehditle uçuş halindeki bir hava nakil vasıtasının veya bunun kontrolunun gayrı kanuni şekilde ele geçirilmesinden ve bir de ayn şekillerde işlenecek müdahale fiillerinden söz edilmektedir. ${ }^{50}$ Hüküm daha yakından incelendiğinde, bunun üç ihtimali kapsadığ görülmektedir: a) Hava nakil vasıtasının ele geçirilmesi tamamlanmıs bir fiildir; b) Hava nakil vasıtasını ele geçirmeğe teșebbüs edilmiş bu-

4714 Eylül 1963 tarihli «Hava Nakil Vasıtalarınđa Işlenen Suçlar ve Diğer Bazı Fiiller Hakkında Sözleşmennin metni için bk. The American journal of international law, 1964, s. 566 vd.; Tokyo Sözleşmesi, 4 Aralık 1969 tarihinde 12 devlet tarafından tasdik edildikten sonra yürüritìge girmiştir. Tasdik eden devletler șunlardır: Çin Cumhuriyeti, Danimarka, Italya, Meksika, Nijerya, Norvec, Filipinler, Portekiz, Isvec, Birleşik Krallik, Amerika, Yukarı Volta. Bu konuda bk. Evans, agm., s. 708 dip not: 68

48 Fitzgerald, Development, s. 241; Ayn mahiyette Evans, agm., s. 708

49 Evans, agm., s. 708

${ }^{50} \mathrm{Bu}$ sözleşmenin uygulanması bakımından bir hava nakil vasıtası, kalkış için enerji verilmesinden pist ïzerindeki iniş yürüyǚşünün bitmesine kadar uçuş halinde sayllır (Sözleşme, m. 1/3). 
lunulmakta veya böyle bir teşebbüs icra edilmektedir; c) Hava nakil vasıtasını ele geçirmek üzere teşebbüiste bulunmağa başlanılmak üzeredir. ${ }^{51}$ İşte Sözleşme, bu sözü edilen durumlarda âkit devletlere, uçağın kontrolunu uçağın kanuni kumandanına iade edecek veya duruma göre bu sonuncunun kontrolunu muhafaza etmesini sağlayacak bütün uygun tedbirleri alma mecburiyetini yüklemektedir. (Sözleşme, m. 11/1). ${ }^{\text {s2 }}$ Bundan başka, söz konusu uçak kendi ülkesine inen devlet, 11. maddenin 1. fikrasında zikredilen șartlar altında kendi ülkesine inen yolcu ve mürettebatın en kısa zamanda yolculuklarına devam etmelerine müsaade etmek ve ayrıca uçağı ve yükünü (cargo), kanuni maliklerine iade etmek zorundadır (Sözleşme, m. 11/2) : ${ }^{33}$

Tokyo Sözleșmesi, âkit devletlerin yetki ve ödevleri konusunda bir çok başka hükümler daha ihtiva etmektedir (Bk. Sözleșme, m. 13/15). Bu hükümler genel olarak, hava nakil vasıtası kumandanının yetki ve ödevlerine ilişkin hükümleri (Bk. Sözleşme, m. 5-10) tamamlamakta ve hava nakil vasıtasindan zorla indirilen șahısların nasıl bir muameleye tâbi tutulacaklarına dair teferruatlı kuralları ihtiva etmektedir. Tokyo Sözleşmesinde ayrıca, hava nakil vasıtasmı gayrı kanuni olarak ele geçiren kimsenin teslimi hakkında da hükümler vardır (Sözleşme, m. 13/1). ${ }^{54}$

Bu ititiarla herşeyden evvel, hava nakil vasitası kumandannın, bu Sözleşme'nin 1. maddesinde öngörülen fiiller (Sözleșme, m. $1 / 1$ a,b ${ }^{55}$ bakımından genel olarak ne gibi yetkilerini olduğunu incclemek gerekir. Zira Sözleşme'nin 11. maddesinde öngörülen, hava nakil vasıtasını veya bunun kontrolunu gayrı kanuni șekilde ela geçirme fiili, aynı zamanda 1. maddenin 1. fikrasında yazılı

s1 Fitzgerald, Gerald: Offences and certain other acts committed on board aircraft: The Tokyo Convention of 1963, The Canadian Yearbook of International Law, 1964, s. 199

52 Fitzgerald, Development, s. 241

\$3 Bk. Fitzgerald, Development, s. 242; Fitzgerald, Offences, s. 199

54 Bk. Fitzgerald, Offences, s. 199

${ }^{55}$ Tokyo Sözleşmesi m. 1/1 a, b’nin metni şöyledir :

1. Bu sözleșme,

a) Ceza hukuku ihlâllerine,

b) Suç teşkil etsin veya etmesinler, hava nakil vasıtasının, hava nakil vasıtası içindeki șahısların veya eşyanın emniyetini tehlikeye düşüren veya tehlikeye düșïrebilecek olan fiillere veya hava nakil vasıtasının nizam ve disiplinini tehlikeye sokan fiillere ilişkin olarak tat. bik edilir. 
fïller içine girer. Öyle ise, uçuş surasında hava nakil vasıtası kumandanınm 1. maddede öngörülen fiillere ilişkin yetkileri, 11. maddede zikredilen ve hava nakil vasitası veya bunun kontrolunu gayrı kanuni olarak ele geçirme fiili bakımından da caridir.

Tokyo Sözleşmesi, hava nakil vasıtasının kumandanına, uçağın emniyetini tehlikeye düşüren veya uçak içindeki disiplin ve nizamı bozacak fiilleri işleyenler hakkında, bazı kısıtlamalar da dahil olmak üzere, makul ve gerekli tedbirleri almak yetkisini tan1maktadır. Tokyo Sözleșmesi'nden anlaşııldığı üzere, ceza kanunu ihlâllerinde de aynı yetkiler vardır (Sözleşime, m. 6/1). Öte yandan, kumandan, gerektiğinde mürattabat ve yolculardan da bu konuda yardım isteyebilir; veya tedbirler konusunda bunları yetkili kılabiIir (Sözleşme, m. 6/2). Bununla beraber, kumandandan gekn talebi yerine getirmek konusunda, mürettabat ile yolcular arasinda fark gözetilmiştír (Bk. Sözleșme, m. 6/2). ${ }^{56}$

Fail hakkında alınan tedbirler ve özellikle kısıtlamanın ne zamana kadar süreceği de önemli bir mesele olarak ortaya çımaktadır. Bu konuda genel kural, kisitlamanin uygulanmasina hava nakil vasıtasının bir devlet ülkesine inmesinden sonra devam edilemeyeceğidir (Sözleșme, m. 7/1). Bununla beraber, ülkesine inilen devletin âkit devletlerden birisi olmayıp da, kısıtlama tedbirine tâbi tutulan kimșenin hava nakil vasitasından indirilmesini kabul etmemesi mümkündür. Bunun gibi, hava nakil vasıtasının hava alanı dışında mecburi iniş yapması ve ilgili şahısı âkit devletlerin yetkili makamlarna teslim edemeyecek durumda bulunması da ihtimal dahilindedir. Sözleşme bu gibi durumlarda, kısıtlama tedbir lerinin iniş noktasının ilerisinde de devam edebileceğini kabul etmiş bulunmaktadır. ${ }^{57}$ Ancak, böyle bir kısıtlama tedbirine tâbi kim. senin uçakta muhafazasının seyrüsefer emniyeti bakımından tehlikeli sayılacağın kabul eden Sözleşme, hava nakil vasıtası kumandanının ilgili kimseyi herhangi bir devlet ülkesinde uçaktan indirebileceğini kabul etmiş bulunmaktadır. Yani, kumandanın ilgili kimseyi uçaktan indirme yetkisi, âkit devletlerin ülkesi ile s1nırlı değildir (Sözleşme, m. 8/1). Bununla beraber, sözü edilen şahısların kendi ülkesinde uçaktan indirilmesine müsaade etmek mecburiyeti, sadece âkit devletler bakımından söz konusudur..$^{58}$ Sözleşmeye taraf teşkil etmeyen devletler bakımından böyle bir mecburi-

\footnotetext{
56 Bk. Fitzgerald, Offences, s. 195

57 Bu konuda bk. Fitzgerald, Development, s. 246

so Fitzgerald, Development, s. 245
} 
yetin mevcut olamayacağı tabiidir. Bunların o şahsın indirilmesini kabul etmeleri, kendi ihtiyarlarına burakılmıştır; kabul etmedikleri takdirde, m. 7/1 a uyarınca, o kiși hakkında ahnmış kısıtlama tedbirleri devam edebilecektir. Hava nakil vasıtası kumandanına, bu gibi tehlikeli şahısları âkit olmayan devletlerin ülkesinde dahi uçaktan indirme yetkisini tanıyan Tokyo Sözleşmesi, bu bakımdan kumandana bazı yetkiler de yüklemektedir. Buna göre, faili âkit olmayan bir devletin ülkesinde uçaktan indirmege karar veren hava nakil vasitası kumandanı, ilgili devleti indirme olayından ve bunun sebeplerinden haberdar etmeğe mecburdur (Sözleşme, m. 8/2).

Kusitlama tedbiri altında bulunan kimseyi âkit olmayan bir devlet ülkesine indirmek yetkisini dahi veren Tokyo Sözleşmesinin, àkit devletler söz konusu olduğunda daha geniş yetkiler ve ödevler tanıacağı tabii idi. Nitekim hava nakil vasıtası kumandanı, uçağın tescil edildiğ iülkenin ceza kanunlarma göre ağır ve ciddi bir suç işlediğini gösterir makul sebepler bulunan kimseyi, ülkesine indiği herhangi bir âkit devletin yetkili makamlarına teslim edebilir (Sözleşme, m. 9/1). Görüldügü üzere, maddedeki yetkinin kullanılabilmesi için, ilgili şahıs hakkında inişten evvel m. 6/1'de öngörülen kısıtlama tedbirinin alınmış olması şart değildir. Eğer bu kimseler esasen kısitlama tedbirine tâbi tutulmuşlarsa, maddede sarahat bulunmamasına rağmen, kumandanın bu yetkiye sahip olduğunu kabul etmek gerekir ${ }^{59}$ Zira, evvelden kisitlamaya tâbi tutulmamıs kimse hakkında bu yetkiyi kabul eden Sözleșme'nin, esasen kısıtlama tedbirinin konusunu teşkil etmiş bulunan ve daha tehlikeli olan şahıs bakımınctan ayn yetkiyi kabul edemeyeceği düşüinülemez. Ancak Sözleşme, m. 8'de olduğu gibi burada da, kumandana bazı ödevler yüklemektedir. Bir kere kumandan herşeyden evvel, ülkesine inerek söz konusu şahsı teslim etmek istediği âkit devlet makamlarm, bu niyetinden ve bunun sebeplerinden haberdar etmek zorundadır. Öte yandan kumandan bu ödevini, pratik bakımdan en kısa zamanda ve mümkünse inmeden evvel yerine getirmelidir. Kumandan bundan başka, elinde bulunan delil ve bilgileri, ilgili şahsı teslim ettiği devletin yetkili makamlaruna verecektir (Sözleșme, m. 9/2,3)..0

Böylece, Tokyo Sözleşmesi'nin hava nakil vasitası kumandanının yetkilerine ilişkin hükümlerini inceledikten sonra, uçak kaçırma fiilı ile ilgili olarak kabul edilen diğer hükümlerin açıklanma-

\footnotetext{
59 Aynı kanaat, Fitzgerald, agm., s. 245

60 Bu konuda ayrica bk. Fitzgerald, Development, s. 246, 247
} 
sına geçmek gerekmektedir. Bunlar esas itibariyle Sözleşme'nin 13-15. maddeleri arasında yer almakta ve özellikle ülkesine inilen devletin yetkilerini düzenlemektedirler. Ayrıca, teslim edilen șahsın teminatları ve uçağın ve yükünün (cargo) iadesi gibi hususlarda da bazı kurallarnn mevcut bulunduğu görünmektedir.

Tokyo Sözleşmesi'nde herşeyden evvel, üJkesine inilen devlete çeşitli vecibbeler yükleyen hükümlere rastlanmaktadır. Bir kere âkit devletler, hava nakil vasıtası kumandanı tarafından uçaktan indirilen veya teslim edilen kimseleri kabul etmeğe mecbur tutulmuşlardır (Sözleşme, m. 13). Nitekim Tokyo Sözleşmesi m. 13/2'ye göre, âkit devletlenden herbiri, 11. maddenin 1. fıkrasında öngörülen bir fiili işlemekten şüpheli her șahsı nezaret altında bulundurmağa veya bu gibi kimselerin hazır bulunmasını temin için gerekli diğer tedbirleri almağa mecburdur. Öte yandan, nezaret altina alma veya diğer tedbirlere başvurma, ülkesine inilen devletin hukukura göre olacaktır. Bununla beraber, nezaret altında bulundurma ve diğer tedbirler, bir ceza koğuşturmasına veya geri verme muamelesine başlayabilmek için makul surette zaruri olan müddetten daha uzun sürremez (Sözleşme, m. 13/2). Bundan başka, ülkesine inilen devlet, nezaret altında bulundurduğu şahsın, vatandașı olduğu devletin en yakın temsilcisi ile muhabere etmesine yardım etmek zorundadır (Sözleșme, m. 13/3). ${ }^{61} 13$. maddeye göre bir şahsı nezaret altına alan devlet, hava nakil vasıtasının tescil edildiği devleti, nezaret alınan şahsın vatandaşı olduğu devleti, ve nihayet lüzumlu gördügüü takdirde, sözui edilen şahsin nezaret altina ahnması ile ilgili devletleri, derhal bu durumdan haberdar et mekle mükelleftir (Sözleșme, m. 13/5).

Sözleșmeye göre, 11. maddede öngörülen fiilin işlenmesini takiben kendi ülkesine inilen devlet, derhal olayla ilgili bir başlangıç soruşturması yapmak zorundadır (Sözleșme, m. 13/4). Bu soruşturmanın gayesi, bir suçun ișlenip işlenmediğini araștırmak ve varılan sonuçların veya diğer delillerin, hava nakil vasıtasının tescil edildiği devlete, nezaret altında bulunduran șahsın vatandaşı olduğu devlete, ve nihayet lüzum görüldư̈̈̆u takdirde, bu şahsın nezaret altında bulundurulması ile ilgili devletlere bir rapor halinde sunulmasını sağlamaktır. Bu itibarla sözü edilen soruşturmayı yapan devlet, soruşturma sonunda bulduklarmı ve diger delilleri bu sayılan devletlere bir raporla bildirmek zorundadır (Sözleșme, m. 13/5). 13. maddeye göre bir şahsı nezaret altına alan dev-

61 Bu konuda ayrica bk. Fitzgerald, Offences, s. 200 
let muhtemelen, kendisinin kaza yetkisinin bulunmadığ hallerde bile yukarıda sözü edilen sorușturmayı yapmağa mecbur olacak$\operatorname{tur}^{62}$

Devletlerin bir suç ișlemiş bulunmak şüphesi altındaki kimseleri ülkelerine kabul etmek hususunda isteksiz olmaları sebe. bi ile, ülkesine inilen devleti, uçaktan indirilmiş bulunup da yolculuğa devam edemeyen veya etmek istemeyen bu gibi şahısları kabule mecbur tutan hükümlere yer verilmemiştir. Böyle durum. larda, ülkesine inilen devletin, suç işlemek şüphesi altındaki bu gibi şahısları hava yolculuklarına başladıkları ülkeye geri yollayabilmek hakkı olduğu kabul edilmiștir (Sözleşme, m. 14/1). Ancak bu yola başvurabilmek için, söz konusu şahsın ülkesine inilen devletin vatandaşı olmaması veya burada daimi ikamet hakkına sahip bulunmaması gerekir (Sözleşme m. 14/1). Bu sebeple, istenmeyen yabancmın ülkesine inilen devletin topraklarından ayrilmada gecikmesi veya başka bir devlete geri gönderilmesi halinde, uçaktan indinme, teslim, nezaret altma alma veya geri gönderme muamelelerinin, söz konusu şahısların ilgili devletin toprağına kabulii șeklinde yorumlanamayacağı hususu, Sözleșme'de hükme bağlanmıs bulunmaktadır. Bundan başka Sözleşme'de, âkit devletlerinin ülkeden tard ve tebid haklarmı etkileyen veya buna smırlamalar getiren herhangi bir hüküm yoktur. Bilâkis, metinde sarahaten, bu Sözleşme hükümlerinin âkit devletlerin tard ve tebide ilişkin iç hukuk kurallarını etkileyemeyeceği öngörülmüş bulunmaktadır (Sözleşme, m. 14/2).

Uçaktan indirilen veya teslim edilen şahıs yolculuğuna devam etmek isterse, bu konuda serbest olacaktır. Ancak kendisinin bu serbestisi, ülkesine inilen devletin iç hukuk kurallarnna göre geri verme veya ceza koğușturması bakımından huzurunun şart olmaması halinde söz konusudur. Nihayet kendisine tanınmıș bulunan bu yolculuğuna devam edebilmek serbestisi, 14. maddenin 1. fikrasına göre hava yolculuğuna başladı̆̆ devletin ülkesine gönderilmesine mani değildir (sözleșme, m. 15/1). Görüldü̈ği üzere ülkesine inilen devlet, prensip itibariyle, yolculuğuna devam etmek isteyen şahsa bu hakkı taniyacaktır. Bununla beraber ülkesine inilen devlet, gerek geri verme gerekse ceza koğuşturması bakımından huzuru şart olan kimseye, yolculuğa devam etmek serbestisini tanımayabilecektir. Aynı şekilde, m. 15/1'de yer alan hüküm, suç-

${ }^{62}$ Fitzgerald, Development, s. 248 
Iunun m. 14/1'de öngörülen devlete geri gönderilmesine de mani değildir..$^{63}$

Nihayet, ülkesine inilen âkit devlet, elinde bulundurduğu kimsenin korunması ve emniyeti bakımından, kendi vatandaşlarına bu gibi hallerde tanıdığından daha az teminath bir muamelede bulunmamak mecburiyetindedir. Bununla beraber, ülkesine inilen devletin, yabanciların kabulüne, suçluların geri verilmesine ve tard ve tebid hakkına ilişkin iç hukuk kuralları saklıdır (Sözleşme, $m$. 15/2). Yani, ülkesine inilen devletin bu sayılan hususlara ilişkin iç hukuk kurallarmı uygulamak sureti ile elinde bulundurduğu şahsı geri vermesi veya ïlkesinden çıkarması, yukarıda sözü edilen teminat sağlama mecburiyetinin ihlâli anlamına gelmeyecektir.

Tokyo Sözleşmesi'nin buraya kadar açıklanan ve uçak kaçırma fïllerine ilişkin hükümleri, fazlaca teferruatlı olmalarından dolayı tenkide uğramıştır. Nitekim Sözleșme'nin kabul edildiği korferansta, ülkesine inilen devletin yetki ve ödevlerine ilişkin hü. kümlerin böyle bir metin için fazlaca teferruatl olduğu ifade edilmiştir. Bununla beraber, sözïi edilen tenkidin ne derece geçerli olduğu, Sözleşme'nin uygulanmasından elde edilen tecrübelerle ortaya çıkacaktır. Ote yandan, fail bakımından geniş ölçüde teminat getirici hükümler kabul edilmiş olması, Sözleşménin olumlu bir yanını ortaya koymaktadır..$^{64}$

Bütün bunlara rağmen, 1963 tarihli Tokyo Sözleșmesi'nin uçak kaçırma füilleri ve özellikle bunların faillerinin cezalandırla- . bilmeleri bakımından yeterli olmadığını söylemek de gerekmektedir. Zira daha evvel bir başka vesile ile de ifade edildiği üzere, Tokyo Sözleşmesi, uçak kaçırma fiillerini milletlerarası suç haline getirmediği gibi, âkit devletleri bu filleri kendi iç hukukları bakimından suç saymağa da zorlamamaktadır. Nitekim, Tokyo Sözleşmesi'nin uçak kaçırma füllerine ilişkin hükümlerinin esas itibariyle uçağın ve içindeki eşyanm maliklerine iadesini, uçağın yolculuğa devamının mümkün kılınmasını gaye edinip; suçlunun cezaen koğușturulması hususuna ilișkin bir düzenleme getirmemesi bunu göstemmektedir. ${ }^{65}$ Ceza koğușturmasının bu fillerin işlenmesini önleyecek etkili bir çare teșkil ettiği düşünülüirse, herşeyden evvel, fiili milletlerarası suç haline getirmek yahut da devletleri fiili iç hukuk bakımından suç sayan yasama değișiklikleri yapmağa zor-

$63 \mathrm{Bu}$ konuda bk. Fitzgerald, Offences, s. 200

6* Fitzgerald, Offences, s. 200-201

${ }^{6}$ Evans, agm., s. 706 
lamak ve bir de faillerin geri verilmesine rıza göstermek sureti ile failin ülkesinden yolculuğa başladığı devlete veya hava nakil vasıtasının tescil edildiği devlete geri verilmesini mümkün kulmak gerekir. Nihayet, uçağın ülkesine indiği devletin faiili cezalandırabileceğini kabul etmek icap eder. ${ }^{6 j}$ Ancak, fiilin siyasi saikle işlenmesi halinde geri verme bakımından doğacak güçlükleri ve bu yönden yeknesak bir uygulamanın zorluklarnn unutmamak gerekir.67

66 Evans, agm., s. 706, 707

${ }^{67} \mathrm{Bu}$ konuda bk. yuk. II., A. vd. 